\title{
GESTALT PSYCHOTHERAPY FOR PEOPLE WHO HAVE SUFFERED SPINAL CORD INJURY AND ARE MOVING BY WHEELCHAIR
}

\author{
Assoc. Prof. Alvydas Soraka \\ Klaipeda Faculty of Lithuanian Academy of Music and Theatre \\ Jurgita Kuliesiene \\ Independent researcher \\ dr. Laima Sapezinskiene \\ Laboratory of Behavioral Medicine (Palanga), Neuroscience Institute, \\ Lithuanian University of Health Sciences
}

\begin{abstract}
The aim of the work was to examine the therapeutic impact of Gestalt individual psychotherapy to the disabled people after spinal cord injury, using experimental structured dance movement and/or life educational program in the community rehabilitation settings. The results. The effectiveness of Gestalt individual psychotherapy and rehabilitation in the local community was essentially described using some major qualitative indices: quality of the involvement into community moment, which is mostly reflected by a person's subjective perception of how the community accepts him/her; the effectiveness of their involvement into the local community, which depends on the duration and quality of the transitional period from rehabilitation in the hospital to the one at home: people who engaged in community activities (for example, wheelchair dancing) faster and more tended to notice the effectiveness of rehabilitation. Conclusion. It is necessary to apply Gestalt individual psychotherapy in the community rehabilitation for the disabled as the psychotherapeutic model is empowering both - a person and communities to help the disabled move from the expectation of being 'care cases' to enabling their ability to fulfil personal and social changes accordingly. Specifying the aims of the work, the main results obtained, and the conclusions are drawn.
\end{abstract}

Keywords: Spinal cord injury; local community; rehabilitation and individual Gestalt psychotherapy, wheelchair dancing experiments, education in community. 


\section{Introduction}

Many communities are essentially inaccessible to individuals with mobility impairments, rendering the individual a virtual prisoner in his or her home, completely reliant on family and friends (Burns, O'Connell \& Rathore, 2012). When a person is unable to move independently he/she loses access to communication, which affects not only his/her identity, self-esteem, self-expression and self-realization abilities, but also his/her presence in society: he/she becomes in some way 'invisible' and vulnerable. The disabled become aware of themselves as marginalized members of society, suffering not only physical but also psychological isolation, experiencing negative emotions both towards themselves and towards society, they also face financial hardship in Lithuania.

Spinal cord injury (SCI) medicine and social change practitioners can learn from recent experiences in order to identify, develop and operationalize appropriate interventions for future disasters (Burns, \& et al., 2012). The specific challenges are including: coordination and mobilization; identification and procurement of required expertise; initial survey and assessment; health care delivery; community reintegration and health maintenance; and sustainability and capacity building (Burns, \& et al., 2012).

The people who have suffered SCI and are moving by wheelchair become aware of themselves as marginalized members of society, suffering not only physical but also psychological isolation, experiencing negative emotions both towards themselves and towards society, they also face financial hardship in Lithuania (Soraka, Sapezinskiene, 2008).

Community reintegration and health maintenance identified challenges (Burns et al., 2012). A primary goal of rehabilitation is successful community reintegration (Burns et al., 2012). The reality of this goal in many settings is questionable in Lithuania.

The research problem. The most important aspect of research problem is that patients and people with disabilities, as members of the society, have equal rights regardless of their health problems. They have a right to a better physical, social, psychological and spiritual well-being of their lives. Attitudes towards patients and people who have suffered SCI and are moving by wheelchair are changing in foreign societies and in Lithuania, with the tendency to accept them as equal members of society and to be included in social institutions (Sapezinskiene, 2006).

The aim of the work. To examine the therapeutical impact of Gestalt individual psychotherapy to the disabled people after spinal cord injury, using experimental structured dance movement and/or life educational program in the rehabilitation settings. 


\section{The Social Change and Social Healing from Viewpoint of the Individual Gestalt Psychotherapy}

For people after trauma, suffering from spinal cord injury and moving by the help of the wheelchair the major change happens in their social life. Metaphorically speaking their life splits. They are going through a conflict between two lifes: former and present (Sapezinskienè, 2006). People after spinal cord injury by themselves usually divides their life into few periods: before trauma and before cord injury, when they were able to move wihout wheelchair and after - when were already paralysed. The former period, when they do not felt any pain and were healthy and present period, when they always feel pain and inadequate and lost (Sapezinskiene, 2006). Their life stage when they were able to live and move like everybody else, they call - life, the traumatizing, crisis period - death and present time - presence existence. Existence is defined as being, as presence, as way of being of human personality. To exist means to be, to live. First definition of the existence was introduced by Kierkagaard (1813-1855). Healthy (currently not feeling ill) people also similarly are dividing their life when social or psychological trauma happens, when their expectations, relatives are lost, when they are emigrating or changing their social environment (Sapezinskiene, 2006).

\section{Social change}

The term social change to refer to shifts in significant behavioural patterns, values and norms in a culture, society, neighbourhood, community or workplace: sometimes this change is intentional; sometimes it is not. Social change is often supported by movements that inspire discontented members of society to rise up against people who have vested interests in the ways things are and who feel threatened by the uncertainty that change generates (Melnick, 2017). Conflicts gives opportunity for changes. Conflict is a field phenomenon in which two different world views, i.e. perceptions of reality, occupy the same place at the same time (Nevis, 2005,Melnick, 2017). Conflict and aggression are normal, occurring at all levels of system - intrapsychic, interpersonal and group, as well as between systems, cultures and societies (Melnick, 2017). When seeking social change one of the effective individual psychotherapy is Gestalt psychotherapy.

\section{Social healing, using Gestalt psychotherapy}

Individual psychotherapy is a place for a disabled to work through psychological issues as these issues emerge within the context of a one on one therapeutic alliance with a psychotherapist (Klein et al., 2013). Considerable evidence links the concept of therapeutic alliance with psychotherapy outcome for a "wide range of diagnoses in populations. One of the most eligible definitions of the Gestalt psychotherapy is 
by Bowman (1998): 'Gestalt therapy is - process psychotherapy with the goal of improving one's contact community and the environment in general, spontaness and authentic dialogue between client and therapist'.

The Gestalt approach has always had a philosophy of inclusion (Melnick, 2017). Gestalt theory and methodology explained as a social healing practice, which aording by Goodman is in the service of creating a better society, rather than as an exercise in self-development (Melnick \& Nevis, 2009). It is valid to raise a question - is Gestalt social intervention, supporting processes or solving problems? (Denham-Vaughan, 2014). Answering to that question we notice that in reality Gestalt is dual social healing intervention including process support and problem solving. The best what is possible to do, is to adapt and to learn good in your own social environment. Using Gestalt psychotherapy is possible purposefully evaluate and perform social healing intervention using such Gestalt constructs as awareness, phenomenology, field, presence, resistance, contact style, energy management and the cycle of experience (Melnick, 2017). The emphasis in Gestalt therapy is on using awareness and the phenomenological approach to establish a full sense of what is in current time, wiihout effort to judge or to change (Taylor, 2014). The Paradoxical Theory of Change is exactly this: change follows when we do not try to be different but instead fully accept how we are. In the case for persons after SCI it is important to draw attention in wich position in the society they find themselves according power position. In this case is eligible social power definition by Nevis and Melnick (2012): 'power as 'an experience occurring between or among people and not something lodged in an individual person or group'. The problem for trauma persons with SCI is 'that they lack the neurobiological functioning to be able to claim their embodied existence in present time (Taylor, 2014). In order to achieve opposite goal for disabled persons, moving by the help of the wheelchair, we apply wheelchairs dance.

\section{Experimental structured wheelchair dance movement}

Dance is a worldwide human activity that involves complex whole body movements through space synchronized to music (Paterson et al., 2018). Scientific studies shows, that dance has impact on health, especially on person's psychological state (Koch et al., 2014).

Dance and movement therapy (DMT) process scheme, using various techniques based on the "here and now" principle. (Goodill, 2005; Sapezinskiene, Soraka, 2016; Terada, 2017) DMT is a psychotherapeutic method, using the dance and movement process to maintain the emotional, cognitive, social, physical functioning of individuals, helping them to become more involved in social relationshipsand social interactions (Sapezinskiene, Soraka, 2016). This principle is the same basic key of the Gestalt psychotherapy technique and is called therapeutic experiment. The movement experience had provided a dynamic opportunity to explore the relationship 
between body and emotions, to evoke awareness and explore choice, and respond to complex situations more effectively. Moving actively, with full effort, can allow strong feelings, such as anger, rage, or joy, to be more consciously experienced and expressed, making them more available for verbal processing. Depending on one's needs in the moment, sensing and responding to the body through movement can be used effectively to regulate or contain emotion. Wheelchair dancing can have a host of positive psychological and physical effects (Saad, 2012).

\section{Research Metodology and Methods}

The methodological basis of the study is defined by the paradigm of social breakthrough, which is eligible for exploring social changes and experiences of individuals after SCI. Phenomenological method of qualitative research was applied for 24 people after spinal cord injury from their local community during three-month period spent in Monciskes, Sventoji (the summer camp for the disabled in Lithuania).

Gestalt individual psychotherapy was used for people who have suffered spinal cord injury and are moving by wheelchair. All the respondents participated in Gestalt group psychotherapy sessions and rehabilitation in the community and half of them (13) participated in the program of wheelchair dance experiments, others (11) - in the life educational programme. Injured, who suffered the traumatizing event 0.3 to 10 years ago, answered the questions of a qualitative in-depth interview and described the impact of individual Gestalt therapy. Participants of the research were interviewed what impact they had of individual Gestalt psychotherapy using experimental structured dance movement and/or life educational program in the rehabilitation settings. Results of the research were processed using content analysis and selecting significant codes.

\section{Results and discussion}

It was determined that similarly to the works of other authors (Kuipers et. al., 2011), three major code indices were attributed to value-based description of a local community as certain 'place' and involvement into the community: social integration; occupation; independent lifestyle. During our study, one more important index that reflected power and powerlessness continuum was discerned. The effectiveness of Gestalt individual psychotherapy and rehabilitation in the local community was essentially described using some major qualitative indices: quality of the involvement into community moment, which is mostly reflected by a person's subjective perception of how the community accepts him/her; the effectiveness of involvement into the local community, which depends on the duration and quality of a transitional period from rehabilitation in the hospital to the one at home: people who engaged in community activities (for example, wheelchair dancing) faster and more tended to notice the effectiveness of rehabilitation. People who participated in wheelchair dance education were less likely to emphasize 
powerlessness and negative image of the community in comparison to those who did not engage in the local community after their rehabilitation in the hospital. We find the same suggestions as Viluckiene (2016): the individuals after spinal cord injury face the disability only during secondary socialization, after internalization of social typifications of disabled body of negative meaning, the overcoming of which and successful socialization requires the involvement into new social group or community, i.e., into a positive social structure, confirming their identity.

\section{Conclusions}

Obtained results showed, that it was properly applied individual gestal psychotherapy using experimental structured wheelchair dance movement and/ or life educational program in the rehabilitation settings. It was established that individual Gestalt psychotherapy impacts positively not only as psychotherapic but also as social changes intervention for the individuals who are suffering after spinal cord injury and moving by the help of wheelchair. According to Bowlby (1988), in psychotherapy, the therapist "provides conditions in which his patient can explore his representational models of himself and his attachment figures with a view to reappraising and restructuring them'. In individual Gestalt psychotherapy the attachment process takes place with the psychotherapist and the client's therapeutic process unfolds within the safety and protection of this one on one relationship. It is necessary to apply a psychotherapeutic model empowering a person and communities to help the disabled move from the expectation of being 'care cases' to enabling their ability to fulfil personal and social changes accordingly. Gestalt individual psychotherapy and rehabilitation of the disabled was and still remains one of the main ways of integrating into the society with a malfunctioning and limited function.

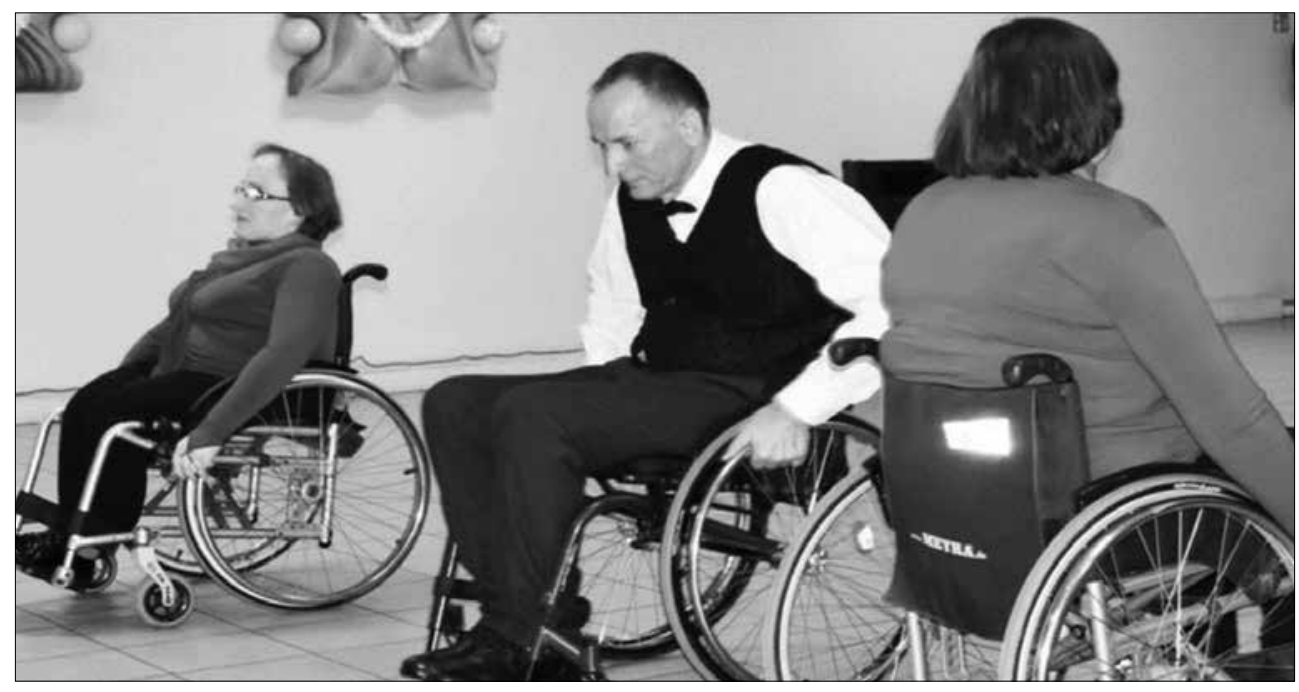




\section{Literature}

Berger, P., Luckmann, T. (1999). Socialinis tikrovès konstravimas. Vilnius: Pradai.

Bowman, Ch.E. (1998). Definitions of Gestalt Therapy: Finding Common Ground. Gestalt Review. 2(2), 97-107.

Burns A.S., O'Connell C.O., Farooq A. and Rathore F.A. (2012). Meeting the Challenges of Spinal Cord Injury Care Following Sudden Onset Disaster - Lessons Learned. J Rehabil Med, Special Report, 44, 414-420.

Denham-Vaughan, S. (2014). Gestalt as social intervention: supporting a process or repairing a problem? In the book A review of Mending the World, A Social Healing Interventions by Gestalt Practitioners Worldwide. British Gestalt Journal, $8-27$.

Goodill, Sh.W. (2005). An Introduction to Medical Dance. Movement Therapy. Health Care in Motion. London: Jessica Kingsley Publishers.

Klein, A., Markowitz, J., Rothbaum, B., Thase, M., Fisher, A., \& Kocsis, J. (2013) The Relationship between the Therapeutic Alliance and Treatment Outcome in Two Distinct Psychotherapies for Chronic Depression. Journal of Consulting and Clinical Psychology,4, 627-638.

Koch S.C., Kunz T. Lykou S.; Cruz R. (2014). Effects of Dance Movement Therapy and Dance on Health-Related Psychological Outcomes: A Meta-Analysis. The Arts in Psychotherapy, 41, 46-64.

Kuipers et. al., (2011). Descriptions of community by people with spinal cord injuries: concepts to inform community integration and community rehabilitation. International Journal of Rehabilitation Research, 34(2), 167-174.

Melnick, J., \& Nevis, E.C. (Ed.) (2012). Mending the World: Social Healing Interventions by Gestalt Practitioners Worldwide. California: Gestalt Press.

Melnick, J. (2017). A Gestalt approach to social change. British Gestalt Journal, 26(1), 17-27.

Patterson, K.K., Jennifer S. Wong, J.S., Erik C. Prout, E.C. \& Brooks, D. (2018). Dance for the rehabilitation of balance and gait in adults with neurological conditions other than Parkinson's disease: A systematic review.

Saad, G.L.M. (2012). The Connected Dance chair: a Study into the Psychological Impact of Using an online "Automated Wheelchair for Dancing". Master of Science In Human Technology Interaction, Einhoven.

Sapezinskas, G., Soraka, A. (2010). Sportinių šokių taikymo neigaliesiems, judantiems vežimèlio pagalba, teorinis pagrindas. Kūrybiniai metodai reabilitacijoje: tarptautinès mokslinès-praktinès konferencijos pranešimų medžiaga. Klaipėda: Klaipėdos universiteto leidykla, pp.88-98.

Sapezinskiene, L. (2006). Expression of team-based organization in Lithuanian rehabilitation institutions. Doctoral Dissertation: Social Sciences, Sociology (05S). Kaunas University of Technology. 
Sapezinskiene, L., Soraka, A. (2016) Dance and movement therapy approaches for patients and disabled clients: theoretical, methodological and practical peculiarities. Biological Psychiatry and Psychopharmacolog. 18(1), 14-21.

Soraka, A., Sapezinskiene, L. (2008). Šokio judesio terapinis poveikis ligoniams po nugaros smegenų pažeidimo, priklausomiems nuo vežimèlio. Biologinè psichiatrija ir psichofarmakologija. (2), 15-20.

Soraka A, Svediene L, Sapezinskiene L. (2009). Dance Movement Impact on Independence and Balance of People with Spinal Cord Injuries During Rehabilitation. In: 10th Congress of European Federation for Research in Rehabilitation - EFRR; 2009 September 9-12; Riga (Latvia). Bologna: Medimond, 37-40.

Taylor, M. (2014). Trauma Therapy and Clinical Practice. Neuroscience, Gestalt and the Body. England: Open University Press.

Terada, K., Satonaka, A., Terada, Y. \& Suzuki, N. (2017). Training effects of wheelchair dance on aerobic fitness in bedridden individuals with severe athetospastic cerebral palsy rated to GMFCS level V, Eur. J. Phys. Rehabil. Med. 53 (5), 744-750.

Viluckiene, J. (2016). The Congenital Motor Disability Experienced as Commonsense. Socialinis darbas. Patirtis ir metodai, 17 (1), 101-115. 


\title{
GEŠTALTO PSICHOTERAPIJA ŽMONE்MS, PATYRUSIEMS STUBURO SMEGENŲ PAŽEIDIMUৃ IR JUDANTIEMS VEŽIMĖLIU
}

\author{
Alvydas Soraka \\ Lietuvos muzikos ir teatro akademijos Klaipedos fakultetas \\ Laima Sapežinskienè \\ Lietuvos sveikatos moksly universiteto Medicinos akademijos \\ Neuromokslu institutas, Elgesio medicinos laboratorija
}

\section{Jurgita Kuliešienė}

Nepriklausoma tyrëja

\section{Santrauka}

Po traumos ir negalėdamas savarankiškai judèti žmogus netenka bendravimo galimybių, kas paveikia ne tik jo tapatybę, savigarbą, saviraišką ir savirealizacijos gebejjimus, bet ir jo buvimą visuomeneje: jis tampa tarsi „nematomas“ ir pažeidžiamas.

Tyrimo problema. Užsienio visuomenèse ir Lietuvoje keičiasi požiūris ị pacientus ir nugaros smegenų pažeidimų patyrusius žmones, kurie juda neigaliųjų vežimèliais, bet neaišku, kaip juos priimti: kaip lygiaverčius visuomenès narius ir ịtraukti ị socialines institucijas (Sapežinskienè, 2006).

Darbo tikslas. Ištirti geštalto individualios psichoterapijos poveikị neigaliesiems po nugaros smegenų pažeidimo, judantiems vežimèliu, naudojant eksperimentinę struktūrizuotą šokio judesio ir (arba) gyvenimo edukacijos programą reabilitacijos aplinkoje.

Tyrimų metodologija ir metodai. Tyrimo metodologinį pagrindą apibrèžia socialinio proveržio paradigma, tinkama tirti socialiniams pokyčiams ir asmenų patirčiai po nugaros smegenų pažeidimų. Buvo taikyti kokybinio tyrimo fenomenologiniai metodai. Tyrimas vyko neiggaliesiems skirtoje stovykloje Lietuvoje, Monciškèse. Vasaros stovyklos, vykusios tris mėnesius, metu individuali, priartinanti prie poreikių, geštalto psichoterapija buvo taikyta žmonėms, patyrusiems nugaros smegenų pažeidimų ir judantiems neigaliųu vežimėliais. Visi 24 respondentai dalyvavo geštalto individualioje psichoterapijoje ir reabilitacijoje bendruomenejje, pusė jų (13) - eksperimentinėje struktūruoto šokio - judesio su vežimėliais - programoje, kiti (11) - gyvenimo edukacinèje programoje. Neigalieji, patyrę traumuojantị ịvykị prieš $0,3-10$ metų, atsakè ị kokybinio giluminio interviu klausimus ir aprašė individualios geštalto psichoterapijos poveikį. Tyrimo rezultatai buvo apdorojami naudojant turinio analizę ir parenkant reikšmingus kodus.

Rezultatai ir išvados. Buvo apibrèžti sutampantys ir su kitų autorių darbais (Kuipers et. al., 2011) trys pagrindiniai kodų indeksai: įsitraukimo ị bendruomenès veiklą kokybė, kurią dažniausia atspindi subjektyvus žmogaus suvokimas, kaip bendruomenè ji priima; įsitraukimo ị vietos bendruomenę veiksmingumas, kuris priklauso nuo pereinamojo laiko- 
tarpio nuo reabilitacijos ligoninejje iki namų trukmės ir kokybės; galios ir bejègiškumo kontinuumas. Respondentai, dalyvavę struktūruoto šokio - judesio su vežimèliais edukacijoje, rečiau pabrèžè bejègiškumą ir neigiamą bendruomenès ịvaizdi, palyginti su tais, kurie po reabilitacijos ligoninèje nedalyvavo vietos bendruomenès veikloje. Būtina taikyti ịgalinantị asmenị ir bendruomenes individualios geštalto psichoterapinį modelị, padedantị neịgaliems asmenims pereiti nuo tendencijos, kad jais bus pasirūpinta, prie savo galios atradimo ir savęs igalinimo igyvendinti asmenybès ir atitinkamai socialinius pokyčius. 


\section{AUTORIŲ LYDRAŠTIS}

Autoriaus vardas, pavardė: Alvydas Soraka

Mokslo laipsnis ir vardas: docentas

Darbo vieta ir pareigos: Lietuvos muzikos ir teatro akademijos Klaipedos fakultetas, docentas

Autoriaus mokslinių interesų sritys: daugiau kaip dvidešimt metų darbo patirties šokio edukacijos srityje dirbant su vaikais, paaugliais, suaugusiais individualiai ir poromis

Telefonas ir el. pašto adresas: alvydas.soraka@gmail.com

Autoriaus vardas, pavardė: Laima Sapežinskienė

Mokslo laipsnis ir vardas: socialinių mokslų (organizacijų sociologija) daktarè

Darbo vieta ir pareigos: Lietuvos sveikatos mokslų universitetas, Medicinos akademija, Neuromokslų institutas, Elgesio medicinos laboratorija, Šliūpo g. 7, Palanga, Lietuva; mokslo darbuotoja

Autoriaus mokslinių interesų sritys: dalyvavimas mokslinių tyrimų projektuose, susijusiuose su trauminių patirčių ir psichosomatinių sveikatos problemų tyrinejjimu, psichoterapijos ir šokio - judesio psichoterapijos veiksmingumo, organizacinių pokyčių komandos ir organizacijos organizacinès kaitos tyrimais

Telefonas ir el. pašto adresas: +370 61414 543, marija1000@gmail.com; laima.sapezinskiene@1smuni.lt

Autoriaus vardas, pavardė: Jurgita Kuliešienè

Mokslo laipsnis ir vardas: nèra

Darbo vieta ir pareigos: nepriklausoma tyreja

Autoriaus mokslinių interesų sritys: dalyvavimas mokslinių tyrimų projektuose, susijusiuose su trauminių patirčių ir psichosomatinių sveikatos problemų tyrinejjimu

Telefonas ir el. pašto adresas: +37061622 166, jurga.kuliesiene@gmail.com 


\section{AUTHORS' COVER LETTER}

Author's name and surname: Alvydas Soraka

Academic degree and name: Associate Professor

Workplace and position: Klaipeda Faculty of Lithuanian Academy of Music and Theatre, associate professor

Author's research interests: Over twenty years dance education in patients and outpatient practice, children, adolescents, adults and for individual, couples.

Telephone and e-mail address: alvydas.soraka@gmail.com

Author's name and surname: Laima Sapežinskienė

Academic degree and name: Doctor of Social Sciences (Organization Sociology)

Workplace and position: Lithuanian University of Health Sciences, Medical Academy, Neurosciences Institute, Behavioral Medicine Laboratory, Researcher.

Author's research interests: participation in the research projects relating to the exploration of traumatic experiences and psychosomatic health problems, effectiveness of psychotherapy and dance movement psychotherapy, efficiency of organizational changes of teams and organisations.

Telephone and e-mail address: +370 61414 543, marija1000@gmail.com, laima.sapezinskiene@1smuni.1t

Author's name and surname: Jurgita Kuliešienè Workplace and position: independent researcher

Author's research interests: participation in the research projects relating to the exploration of traumatic experiences and psychosomatic health problems.

Telephone and e-mail address: +37061622 166, jurga.kuliesiene@gmail.com 